\title{
Effects of autoclaving on the physiological action of paclobutrazol
}

\author{
Dimas Mendes Ribeiro, Caroline Müller, Jackson Bedin, Glayton Botelho Rocha, Raimundo \\ Santos Barros*
}

Depto de Biologia Vegetal/Universidade Federal de Viçosa, Viçosa, Brazil; *Corresponding Author: $\underline{\text { rsbarros@ufv.br }}$

Received 3 March 2011; revised 6 May 2011; accepted 25 July 2011.

\begin{abstract}
Besides being employed as an efficient plant growth retardant for field, garden and potted plants, paclobutrazol (PBZ) is also used in laboratory experiments, mainly in aseptic cultures, both in autoclaved and non-autoclaved form. Therefore it is not known if autoclaving can partial or completely inactivate the product, thus decreasing its efficacy. Thus a simple experiment was carried out to assess to what extent the autoclaving process can affect some growth components and dry mass accumulation and partition in sunflower seedlings, by employing the techniques of Plant Growth Analysis. Autoclaving did not modify either qualitative or quantitatively any of the plant responses to PBZ as well their reversions by gibberellic acid.
\end{abstract}

Keywords: Autoclaving; Dry Mass Accumulation; Gibberilins; Growth; Paclobutrazol; Sunflower

\section{INTRODUCTION}

Paclobutrazol [PBZ; common names: Bonzi, ClipperS, Clipper-T, Cultar, PP333; chemical name: IUPAC: (2RS,3RS)-1-4-(chlorophenyl)-4,4-dimethyl-2- $(1 \mathrm{H}, 1,2,4-$ triazol-1-yl)pentan-3-ol] is an efficient plant growth retardant listed for usage by the Plant Growth Regulation Society of America [1]. Its optical enantiomer $2 S, 3 S$ displays a pronounced plant growth regulatory activity, whereas the $2 R, 3 R$ enantiomer is more active in the inhibition of sterol biosynthesis, exhibiting fungicidal properties. The growth retarding form of PBZ (S-enantiomer) keeps certain structural similarities with entkaurene and ent-kaurenol, key compounds in the pathway to gibberellins (GAs) biosynthesis, and hence may inhibit cytochrome $\mathrm{P} 450$ monooxygenases, impairing the oxidation of ent-kaurene to ent-kaurenoic acid [2,3]. As a result PBZ can cause a substantial depletion in the lev- els of active GAs throughout the plant [3], leading to a kind of dwarfism [1]. Some effects of PBZ on plants are: development of dark green color in leaves [2]; stimulation of flowering, likely as a result of a decrease in vegetative growth $[4,5]$; hastened leaf fall in autumn and emergence delay in spring in deciduous plants [2]; yield increase in apples [6], Jathropa curcas [7] and other cultivated species.

Water solubility of PBZ is very poor, about $0.12 \mathrm{mM}$ (35 $\left.\mathrm{mg} \cdot \mathrm{dm}^{-1} ;[1,2]\right)$, the compound being mostly immobile in the phloem sieve tube elements. Due to that when sprayed in the plants its action is much localized. A more uniform distribution is seen when it is provided by trunk injection or soil application, because in this case the product is transported via xylem vessels [8]. This low solubility has brought about some troubles especially when the compound is used under laboratory conditions. For instance in order to achieve reproducible results on the inhibition of seed germination of Townsville stylo (Stylosanthes humilis) PBZ had to be autoclaved [9]. The autoclaved product is also largely employed in aseptic culture experiments [10-12], although the non-autoclaved form is identically used [13-15]. Sometimes the condition of the PBZ (autoclaved or non- autoclaved) employed in the experiments is not even mentioned [16]. Since PBZ is "stable at all temperatures up to $50^{\circ} \mathrm{C}$ for at least six months" $[1,2]$ and that during the autoclaving process temperature as high as $120^{\circ} \mathrm{C}$ is achieved, it is likely that heating leads to degradation of the compound, rendering PBZ completely or partially inactive. As a consequence the effective amount of PBZ that elicits a physiological action is not known when the product is autoclaved. In order to throw some light to this problem a simple assay was designed as to compare the effects of autoclaved and non-autoclaved PBZ on the growth and dry mass accumulation of seedlings of sunflower (Helianthus annuus L.).

\section{MATERIALS AND METHODS}

Seeds of sunflower 'Agará 4' plants were sown in 400 
$\mathrm{cm}^{3}$ plastic pots containing a 2:1:1 mixture of red-yellow latosol soil, sand and cattle manure in a greenhouse in Viçosa $\left(20^{\circ} 45^{\prime} \mathrm{S}, 42^{\circ} 15^{\prime} \mathrm{W}\right)$, Minas Gerais state, Brazil. Upon seedling emergence, soil was fertilized with $0.2 \mathrm{~g}$ of NPK (25-5-20). When ca $7-10 \mathrm{~cm}$ high, seedlings were thinned to two plants per pot. On the occasion 5 $\mathrm{cm}^{3}$ PBZ (10\% a.i.; Wisser Importer, SP, Brazil) suspension (containing 2.5 or $5 \mathrm{mg}$ ) were distributed with a pipette on the soil surface of each pot (day 0, Figure 1 and Table 1).

Autoclaving of PBZ was accomplished in an autoclave (Sercom, Model HA, SP, Brazil), for $20 \mathrm{~min}$, under $121^{\circ} \mathrm{C}$ and a pressure $120 \mathrm{kPa}$. Nine and 16 days after PBZ application, seedling apices were sprayed until complete wetness with a $0.1 \mathrm{mM}$ gibberellic acid $\left(\mathrm{GA}_{3}\right.$; SIGMA, MI, USA) solution also containing $0.05 \%$ Tween 80 . Stem length, as measured from soil surface to the uppermost visible node, was registered at each other day. At the end of the experiment the plants were harvested, their roots were washed and leaves (unfolded $\geq$ $1.5 \mathrm{~cm}$ ) and internode number counted. Following separation roots stems and leaves were oven-dried at $70^{\circ} \mathrm{C}$ for about $72 \mathrm{~h}$, and afterwards their dry mass determined. Organ lengths and dry masses constituted thus the primary data upon which the Growth Analysis techniques were used according to Richards [17] and Hunt et al. [18].

Statistical design was based on a completely random-

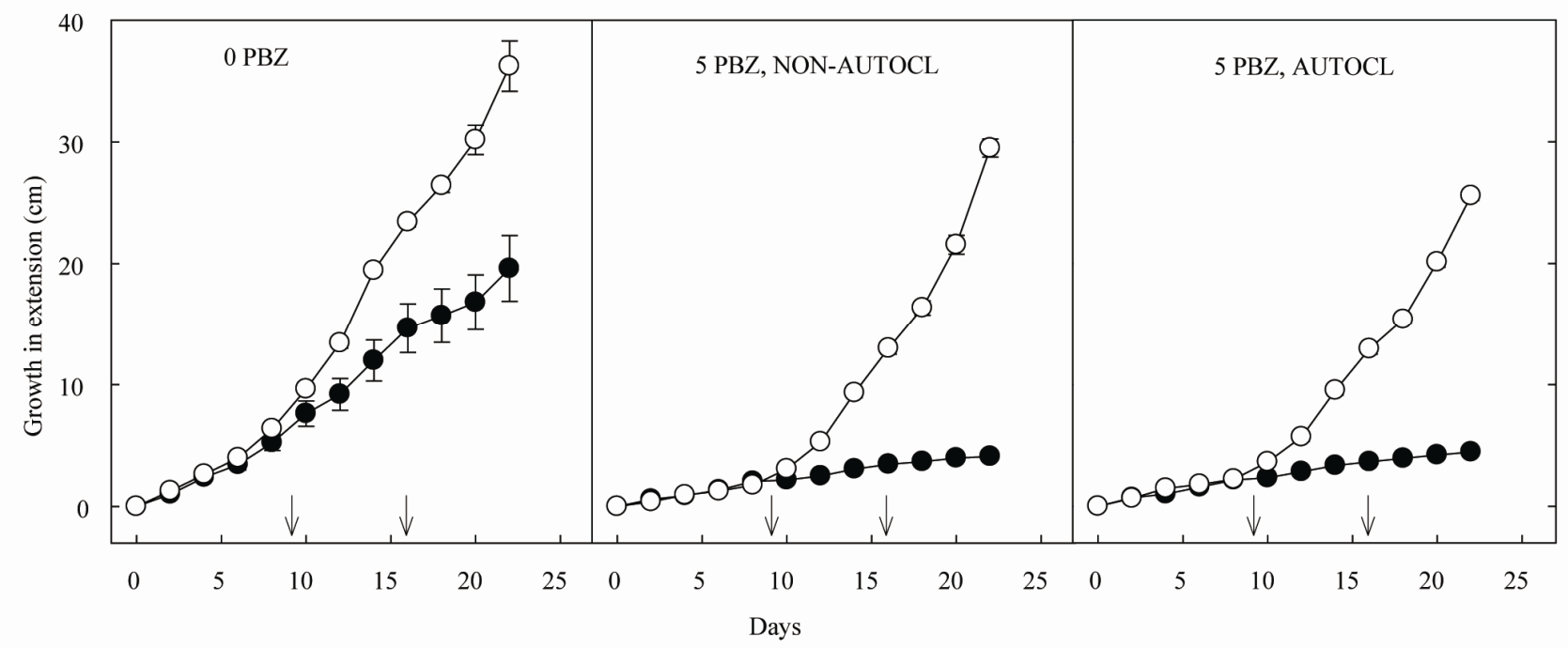

Figure 1. Growth increase in stem length of sunflower seedlings as affected by autoclaved (AUTOCL)- and non-autoclaved (NONAUTOCL)-PBZ applied in the soil surface at the dosage $5.0 \mathrm{mg}$ per pot at the day 0 . At days 9 and 16 following PBZ application, $\mathrm{GA}_{3}(0.1 \mathrm{mM})$ was sprayed at the shoot apex of the plants, as indicated by the arrows. The pattern of growth curves in response to $2.5 \mathrm{mg}$ PBZ per pot was exactly the same as shown in the figure, except for the magnitude of the values. Full circles: -GA 3 ; Hollow circles: $\mathrm{GA}_{3}$-treated. Each point and bars represent means $\pm \mathrm{SE}$ of 10 plants.

Table 1. Increase in stem (STM) length, mean internode (INT) length and stem growth rate of sunflower plants before $\left(0-9^{\text {th }}\right.$ day) and after $\left(10^{\text {th }}-22^{\text {nd }}\right.$ day) the first plant spraying with $\mathrm{GA}_{3}$. In this table and Tables 2 and 3 numbers following PBZ represents its doses (mg) applied in each pot. $\mathrm{GA}_{3}$ was sprayed at the concentration $0.1 \mathrm{mM}$. CTL-control. (Means to be compared within columns; values followed by the same letter do not differ significantly at $5 \%$ by Tukey test. Data analysis by Scott-Knott test also showed that the effects of autoclaved and non-autoclaved PBZ were similar).

\begin{tabular}{|c|c|c|c|c|}
\hline \multirow{2}{*}{ Treatment } & STM length & INT length & \multicolumn{2}{|c|}{ STM growth rate $\left(\mathrm{cm} \cdot\right.$ day $\left.^{-1}\right)$} \\
\hline & $(\mathrm{cm})$ & $(\mathrm{cm})$ & $(0-9$ th day $]$ & $(10-22 n d$ day $)$ \\
\hline CTL & $19.6 \pm 2.7 \mathrm{c}$ & $2.19 \pm 0.30 \mathrm{c}$ & $0.65 \pm 0.08 \mathrm{a}$ & $1.00 \pm 0.15 \mathrm{~b}$ \\
\hline $\mathrm{CTL}+\mathrm{GA}_{3}$ & $36.2 \pm 2.1 \mathrm{a}$ & $3.3 \pm 0.17 \mathrm{a}$ & $0.80 \pm 0.04 \mathrm{a}$ & $2.21 \pm 0.14 \mathrm{a}$ \\
\hline \multicolumn{5}{|l|}{ Non-autoclaved: } \\
\hline PBZ 2.5 & $5.0 \pm 0.3 \mathrm{~d}$ & $1.14 \pm 0.06 \mathrm{~d}$ & $0.31 \pm 0.03 \mathrm{bc}$ & $0.15 \pm 0.01 \mathrm{c}$ \\
\hline PBZ 5.0 & $4.1 \pm 0.3 \mathrm{~d}$ & $0.93 \pm 0.04 \mathrm{~d}$ & $0.26 \pm 0.02 \mathrm{bc}$ & $0.16 \pm 0.01 \mathrm{c}$ \\
\hline $\mathrm{PBZ} 2.5+\mathrm{GA}_{3}$ & $28.1 \pm 0.7 \mathrm{~b}$ & $3.05 \pm 0.14 \mathrm{~b}$ & $0.28 \pm 0.02 \mathrm{bc}$ & $2.06 \pm 0.04 \mathrm{a}$ \\
\hline $\mathrm{PBZ} 5.0+\mathrm{GA}_{3}$ & $29.5 \pm 0.8 b$ & $3.09 \pm 0.05 b$ & $0.22 \pm 0.02 \mathrm{c}$ & $2.20 \pm 0.07 \mathrm{a}$ \\
\hline \multicolumn{5}{|l|}{ Autoclaved: } \\
\hline PBZ 2.5 & $5.4 \pm 0.3 \mathrm{~d}$ & $1.17 \pm 0.04 \mathrm{~d}$ & $0.33 \pm 0.01 \mathrm{bc}$ & $0.21 \pm 0.01 \mathrm{c}$ \\
\hline PBZ 5.0 & $4.5 \pm 0.2 \mathrm{~d}$ & $1.00 \pm 0.06 \mathrm{~d}$ & $0.27 \pm 0.02 \mathrm{bc}$ & $0.18 \pm 0.01 \mathrm{c}$ \\
\hline $\mathrm{PBZ} 2.5+\mathrm{GA}_{3}$ & $29.5 \pm 2.2 \mathrm{~b}$ & $3.15 \pm 0.08 \mathrm{ab}$ & $0.39 \pm 0.03 b$ & $2.01 \pm 0.15 \mathrm{a}$ \\
\hline PBZ $5.0+\mathrm{GA}_{3}$ & $25.6 \pm 0.4 \mathrm{~b}$ & $2.78 \pm 0.11 \mathrm{bc}$ & $0.28 \pm 0.02 \mathrm{bc}$ & $1.83 \pm 0.03 \mathrm{a}$ \\
\hline
\end{tabular}


ized distribution with five replicates, each one constituted of a pot with two plants, per treatment. The Tukey mean separation test, at 5\% level, was employed to detect differences amongst treatments. As Scott-Knott test clusters means without superimposing their significances, it was employed further as to subsidize the Tukey's analyses. In this way probable differences and similarities among the treatments could be further confirmed.

\section{RESULTS AND DISCUSSION}

The first signs of PBZ action were observed by the development of a dark-green color in growing leaves [2] 3 - 4 days after application of the product to the soil. The new appearing leaves then became smaller [19], exhibiting a thicker and wrinkled aspect [20]. Thereafter the growth rate of PBZ-treated plants decreased substantially (Figure 1, Table 1) and the apical internodes and leaves started displaying a rosette form. This dwarfism syndrome was similarly exhibited by autoclaved and non-autoclaved PBZ-treated plants, with no quantitative differences between the plants of the two treatments (Tukey and Scott-Knott tests, 5\% level). Each one of those symptoms was properly reverted by $\mathrm{GA}_{3}$, the responses also not being affected by the autoclaving of PBZ.

Stem growth pattern followed the well-characterized sigmoidal logistic model $[17,18]$. As Figure 1 and Table 1 show stem length resulted much longer in the control and in all $\mathrm{GA}_{3}$-treated plants than in PBZ-inhibited plants. Again, differences in stem length in response to autoclaved and non-autoclaved PBZ were too small to have assumed any statistical significance. A dramatic change in the growth pattern of PBZ-treated plants was observed following $\mathrm{GA}_{3}$ application (Figure 1). Growth rates increased substantially, sometimes higher than 10fold (Table 1); in this way, at the end of the experiment the stem length of these plants surpassed that of the control non-treated plants.
Leaf and internode number (about the half of the leaf number, within a range 10.0 - 11.6 internodes per plant, not shown) were not affected by any of the treatments, showing that in sunflower they constitute highly conserved traits. Hence the much reduced stem length caused by PBZ (Figure 1, Table 1), was a consequence of the very shorter internodes, an effect also reverted by $\mathrm{GA}_{3}$ notwithstanding whether PBZ was autoclaved or not (Table 1).

Total dry mass accumulated per plant did not respond to any of the treatment, autoclaved PBZ included (Figure 2, Table 2). In this context, in some plant species GAs affect positively the net $\mathrm{CO}_{2}$ assimilation $(A)$ whilst in others it is not affected [21]. Sunflower thus, seems to belong to the latter group. This fact must be a consequence of a similar A displayed by PBZ-treated and nontreated sunflower seedlings [22]. Similarly dry mass allocation to leaves and to the stem-root system was not affected either by PBZ or $\mathrm{GA}_{3}$ (Figure 2, Table 2). The regulators, however, affected the dry mass partition within the stem-root system (see below).

Since leaf dry mass per plant was not affected by the regulators which also did not affect leaf number, the mean individual leaf dry mass was also kept similar amongst all the treatments (range $79.0-99.0 \mathrm{mg}$, not shown). As a consequence of the similar total dry mass per plant and also of a similar leaf dry mass per plant, leaf mass ratio (LMR), the ratio between leaf to total plant dry mass [23], did not show any significant difference among the treatments (Table 3). Though the mean individual leaf dry mass did not vary among the treatments, they profoundly affected leaf size as mentioned above. As described earlier leaf size was drastically reduced by PBZ, as also found in Zinnia and Geranium [24]. In order to hold the same dry mass in a much reduced area PBZ-treated leaves have to be thicker, a point examined in a side experiment with the third uppermost leaves in the stem (showing symptoms of PBZ action).

Table 2. Dry mass (DRM) of roots (ROT), stem (STM), leaves (LFY) of sunflower plants. Also shown are stem plus root (STM + ROT), total (TOT) dry mass per plant, and mean internode (INT) dry mass. (Means to be compared within columns; values followed by the same letter do not differ significantly at $5 \%$ level by Tukey test. Data analysis by Scott-Knott test also showed that the effects of autoclaved and non-autoclaved PBZ were similar).

\begin{tabular}{|c|c|c|c|c|c|c|}
\hline Treatment & ROT (g) & STM (g) & LFY (g) & STM+ROT (g) & TOT $(\mathrm{g})$ & INT (mg) \\
\hline CTL & $0.56 \pm 0.07 \mathrm{abcd}$ & $0.85 \pm 0.14 \mathrm{ab}$ & $0.75 \pm 0.04 \mathrm{a}$ & $1.40 \pm 0.16 \mathrm{a}$ & $2.15 \pm 0.16 \mathrm{a}$ & $81 \pm 15 a b c$ \\
\hline $\mathrm{CTL}+\mathrm{GA}_{3}$ & $0.38 \pm 0.03 \mathrm{~d}$ & $1.05 \pm 0.11 \mathrm{a}$ & $0.77 \pm 0.03 \mathrm{a}$ & $1.43 \pm 0.13 \mathrm{a}$ & $2.20 \pm 0.17 \mathrm{a}$ & $100 \pm 10 \mathrm{a}$ \\
\hline \multicolumn{7}{|l|}{ Non-autoclaved: } \\
\hline PBZ 5.0 & $0.70 \pm 0.08 \mathrm{ab}$ & $0.50 \pm 0.06 \mathrm{c}$ & $0.81 \pm 0.05 \mathrm{a}$ & $1.20 \pm 0.13 \mathrm{a}$ & $2.01 \pm 0.17 \mathrm{a}$ & $46 \pm 5 d$ \\
\hline $\mathrm{PBZ} 2.5+\mathrm{GA}_{3}$ & $0.49 \pm 0.06 \mathrm{bcd}$ & $1.06 \pm 0.06 \mathrm{a}$ & $0.80 \pm 0.03 \mathrm{a}$ & $1.55 \pm 0.10 \mathrm{a}$ & $2.36 \pm 0.13 \mathrm{a}$ & $92 \pm 7 \mathrm{a}$ \\
\hline PBZ $5.0+\mathrm{GA}_{3}$ & $0.51 \pm 0.04 \mathrm{bcd}$ & $1.05 \pm 0.02 \mathrm{a}$ & $0.91 \pm 0.03 \mathrm{a}$ & $1.56 \pm 0.03 \mathrm{a}$ & $2.47 \pm 0.02 \mathrm{a}$ & $94 \pm 2 \mathrm{a}$ \\
\hline \multicolumn{7}{|l|}{ Autoclaved: } \\
\hline PBZ 2.5 & $0.80 \pm 0.06 \mathrm{a}$ & $0.56 \pm 0.04 \mathrm{bc}$ & $0.74 \pm 0.09 \mathrm{a}$ & $1.36 \pm 0.09 \mathrm{a}$ & $2.10 \pm 0.17 \mathrm{a}$ & $57 \pm 3 \mathrm{bcd}$ \\
\hline PBZ 5.0 & $0.64 \pm 0.05 \mathrm{abc}$ & $0.53 \pm 0.05 b c$ & $0.87 \pm 0.04 \mathrm{a}$ & $1.17 \pm 0.07 \mathrm{a}$ & $2.04 \pm 0.11 \mathrm{a}$ & $51 \pm 5 \mathrm{~cd}$ \\
\hline $\mathrm{PBZ} 2.5+\mathrm{GA}_{3}$ & $0.47 \pm 0.04 \mathrm{bcd}$ & $1.02 \pm 0.08 \mathrm{a}$ & $0.91 \pm 0.07 \mathrm{a}$ & $1.49 \pm 0.11 \mathrm{a}$ & $2.40 \pm 0.17 \mathrm{a}$ & $90 \pm 4 \mathrm{a}$ \\
\hline $\mathrm{PBZ} 5.0+\mathrm{GA}_{3}$ & $0.40 \pm 0.03 \mathrm{~cd}$ & $0.99 \pm 0.03 \mathrm{a}$ & $0.88 \pm 0.07 \mathrm{a}$ & $1.39 \pm 0.06 \mathrm{a}$ & $2.27 \pm 0.12 \mathrm{a}$ & $87 \pm 4 \mathrm{ab}$ \\
\hline
\end{tabular}




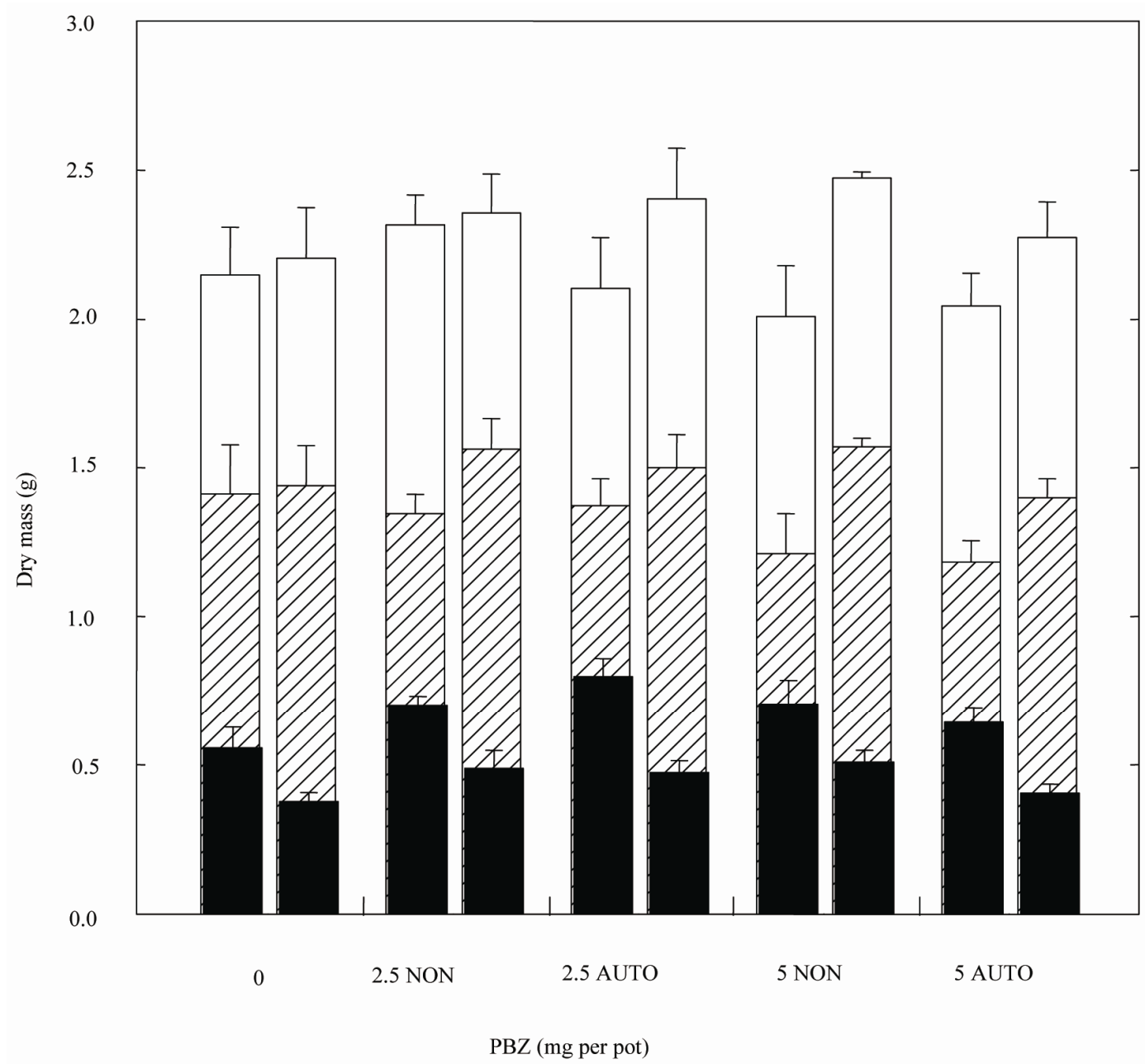

Figure 2. Dry mass accumulation by sunflower seedlings and partitioning among leaves (hollow rectangles), stem (hatched rectangles) and roots (full rectangles). Total plant dry mass, total leaf dry mass and stem plus root dry mass did not show any statistical significance among the treatments; differences were exhibited between shoot and root dry mass of plants of the several treatments (Tukey's and Scott-Knott's tests, 5\% level). Figures represent the amounts of PBZ in mg applied to each pot. For each pair of data of control (0), autoclaved (AUTO)- and non-autoclaved (NON)-PBZ treatments, the $1^{\text {st }}$ element of the pair refers to $-\mathrm{GA}_{3}$ treatment and the second one to $+\mathrm{GA}_{3}$ treatment. Bars represent $\pm \mathrm{SE}$ around means of 10 plants.

Specific leaf area (SLA, obtained by dividing the area by leaf dry mass [23]), was about 31.7 in control leaves, 26.5 - 28.8 in PBZ-treated leaves and $36.9-43.0 \mathrm{~m}^{-2} \cdot \mathrm{kg}^{-1}$ in $\mathrm{GA}_{3}$-treated leaves. PBZ (autoclaved and non-autoclaved) thus induced the formation of small and thicker leaves, an effect promptly reverted by $\mathrm{GA}_{3}$.

Shoot-root system dry mass as a whole did not respond to any of the regulators employed (Figure 2, Table 2). Since total dry mass per plant was not affected as well, the ratio stem-root to total plant dry mass (range $0.57-0.66$ ) was equally not affected by them (Table 3 ). Within that system itself each one stem and root dry mass was, nevertheless, greatly affected (Figure 2, Table 3). As shown in Figure 1, stem expansion was highly responsive to the regulators. Hence the system stem-root seemed to be the main target for the action of PBZ and $\mathrm{GA}_{3}$. When dry mass of stems and roots were considered separately they showed a large variation in response to treatments (Figure 2, Tables 2 and 3), PBZ (autoclaved and non-autoclaved) favoring dry mass allocation to roots and $\mathrm{GA}_{3}$ to stems. Hence the ratio root to total plant dry mass (root mass ratio, RMR; [22]) was larger in PBZ-treated plant whereas stem to total plant dry mass (stem mass ratio, SMR) was larger in all (including the reversion of $\mathrm{PBZ}$ effects) $\mathrm{GA}_{3}$-treated plants (Table 3). In agreement with these observations, the root biomass accumulation was also increased in uniconazoland PBZ-treated plants of Arabidopsis [25]. Moreover these data are in close accordance with recent genetic studies which revealed good correlation between a low 
Table 3. Some allometric relationships in sunflower plants as affected by PBZ and GA . Root mass ratio (RMR, fraction of root mass to total plant dry mass); stem mass ratio (SMR, fraction of stem mass to total plant dry mass), leaf mass ratio (LMR, fraction of leaf mass to total plant dry mass); STM + ROT:TOT (stem plus root to total plant dry mass); root to shoot dry mass (ROT:SHT); root to stem plus root dry mass (ROT:STM + ROT); and dry mass distribution over the stem length unit (DRM/LNT). (Means to be compared within the columns. Values followed by the same letter do not differ significantly at $5 \%$ level by Tukey test. Data analysis by Scott-Knott test also showed that the effects of autoclaved and non-autoclaved PBZ were similar).

\begin{tabular}{|c|c|c|c|c|c|c|c|}
\hline Treatment & RMR & SMR & LMR & $\begin{array}{c}\text { STM + ROT: } \\
\text { TOT }\end{array}$ & ROT:SHT & $\begin{array}{c}\text { ROT: } \\
\text { STM + ROT }\end{array}$ & $\begin{array}{l}\text { STM DRM/ } \\
\text { LNT }\left(\mathrm{g} \cdot \mathrm{m}^{-1}\right)\end{array}$ \\
\hline CTL & $0.26 \pm 0.03 \mathrm{~cd}$ & $0.39 \pm 0.05 \mathrm{a}$ & $0.35 \pm 0.03 \mathrm{a}$ & $0.64 \pm 0.07 \mathrm{a}$ & $0.35 \pm 0.05 \mathrm{~cd}$ & $0.41 \pm 0.05 \mathrm{~b}$ & $3.6 \pm 0.8 \mathrm{~b}$ \\
\hline $\mathrm{CTL}+\mathrm{GA}_{3}$ & $0.17 \pm 0.01 \mathrm{e}$ & $0.47 \pm 0.02 \mathrm{a}$ & $0.35 \pm 0.02 \mathrm{a}$ & $0.64 \pm 0.04 \mathrm{a}$ & $0.21 \pm 0.01 \mathrm{e}$ & $0.27 \pm 0.01 \mathrm{c}$ & $2.6 \pm 0.2 b$ \\
\hline \multicolumn{8}{|l|}{ Non-autoclaved: } \\
\hline PBZ 2.5 & $0.30 \pm 0.01 b c$ & $0.27 \pm 0.01 \mathrm{~b}$ & $0.42 \pm 0.02 \mathrm{a}$ & $0.58 \pm 0.04 \mathrm{a}$ & $0.44 \pm 0.03 \mathrm{bc}$ & $0.53 \pm 0.02 \mathrm{a}$ & $4.9 \pm 0.4 \mathrm{a}$ \\
\hline PBZ 5.0 & $0.35 \pm 0.02 \mathrm{ab}$ & $0.24 \pm 0.01 \mathrm{~b}$ & $0.41 \pm 0.02 \mathrm{a}$ & $0.59 \pm 0.05 \mathrm{a}$ & $0.54 \pm 0.03 \mathrm{ab}$ & $0.59 \pm 0.08 \mathrm{a}$ & $4.9 \pm 0.3 \mathrm{a}$ \\
\hline PBZ $2.5+\mathrm{GA}_{3}$ & $0.20 \pm 0.01 \mathrm{de}$ & $0.45 \pm 0.01 \mathrm{a}$ & $0.34 \pm 0.01 \mathrm{a}$ & $0.66 \pm 0.02 \mathrm{a}$ & $0.26 \pm 0.02 \mathrm{de}$ & $0.31 \pm 0.02 b c$ & $3.0 \pm 0.1 \mathrm{~b}$ \\
\hline $\mathrm{PBZ} 5.0+\mathrm{GA}_{3}$ & $0.21 \pm 0.02 \mathrm{de}$ & $0.42 \pm 0.01 \mathrm{a}$ & $0.37 \pm 0.01 \mathrm{a}$ & $0.63 \pm 0.02 \mathrm{a}$ & $0.26 \pm 0.03 \mathrm{de}$ & $0.33 \pm 0.02 b c$ & $3.0 \pm 0.1 \mathrm{~b}$ \\
\hline \multicolumn{8}{|l|}{ Autoclaved: } \\
\hline PBZ 2.5 & $0.38 \pm 0.02 \mathrm{a}$ & $0.27 \pm 0.01 \mathrm{~b}$ & $0.35 \pm 0.02 \mathrm{a}$ & $0.65 \pm 0.05 \mathrm{a}$ & $0.62 \pm 0.05 \mathrm{a}$ & $0.59 \pm 0.02 \mathrm{a}$ & $4.8 \pm 0.2 \mathrm{a}$ \\
\hline PBZ 5.0 & $0.31 \pm 0.03 a b c$ & $0.26 \pm 0.02 b$ & $0.43 \pm 0.01 \mathrm{a}$ & $0.57 \pm 0.02 \mathrm{a}$ & $0.46 \pm 0.03 b c$ & $0.55 \pm 0.03 \mathrm{a}$ & $5.0 \pm 0.4 \mathrm{a}$ \\
\hline PBZ $2.5+\mathrm{GA}_{3}$ & $0.20 \pm 0.01 \mathrm{de}$ & $0.42 \pm 0.01 \mathrm{a}$ & $0.38 \pm 0.01 \mathrm{a}$ & $0.62 \pm 0.02 \mathrm{a}$ & $0.25 \pm 0.01 \mathrm{de}$ & $0.32 \pm 0.01 b c$ & $2.9 \pm 0.1 \mathrm{~b}$ \\
\hline PBZ $5.0+\mathrm{GA}_{3}$ & $0.18 \pm 0.01 \mathrm{e}$ & $0.43 \pm 0.01 \mathrm{a}$ & $0.39 \pm 0.01 \mathrm{a}$ & $0.61 \pm 0.03 \mathrm{a}$ & $0.22 \pm 0.01 \mathrm{de}$ & $0.29 \pm 0.01 \mathrm{c}$ & $3.1 \pm 0.1 \mathrm{~b}$ \\
\hline
\end{tabular}

GA regime and biomass accumulated in the roots [26].

A pattern emerges as to explain the results on dry mass distribution in sunflower plants when the relationships between length and dry mass of the stem as affected by $\mathrm{PBZ}$ and $\mathrm{GA}_{3}$ are taken into account. It is well known that $\mathrm{GA}_{3}$ stimulates stem growth towards the shoot main axis direction which is translated into internode expansion (Figure 1, Table 1). PBZ, on the other hand, inhibits stem elongation leading to much smaller cells. $\mathrm{GA}_{3}$-treated stems accumulate much more dry mass just because they are much longer than PBZtreated stems (Figure 2, Tables 1 and 2). By taking into account the dry mass distribution over the stem length unit, it is seen that both autoclaved and non-autoclaved PBZ-treated stems similarly "concentrate" more dry mass than $\mathrm{GA}_{3}$-treated stems (Table 3), being thus "denser". It is deduced that dry mass accumulation by individual cells of PBZ-treated plants may approach or even reach its potential, what did not absolutely occur in $\mathrm{GA}_{3}$-treated stems.

Given that dry mass accumulation by the stem-root system does not vary with treatments (Figure 2, Table 2) a model can then be proposed that fits to the above facts. In $\mathrm{GA}_{3}$-treated plants stem elongates excessively but dry mass accumulation (about $60 \%$ of dry mass accumulated by PBZ-treated stems, on a length unit basis, i.e., far from its maximum potential, see Table 3 ) does not keep pace with that process, leading to the production of narrower and elongated stems. Nevertheless, due to this high elongation (Figure 1, Table 1), stem constitutes the main sink of the stem-root system and thus in $\mathrm{GA}_{3}$ treated plants little dry mass remains to be allocated to the roots (Table 3). A low root to shoot ratio (or root to stem plus root) thus results (Table 3). In PBZ-treated plants, stems are very short and although they accumulate more dry mass per volume unit ("denser" cells, Ta- ble 3), they are too small to constitute a strong assimilate sink. The surplus of assimilates produced by the plant is then directed towards the roots, what explains the high root to shoot (or root to stem plus root) ratio displayed by PBZ-treated plants (Table 3). Curiously, these calculations led to similar results as the ones obtained in [21] with tomato using much more sophisticated techniques. By working with the $A 70$ (moderately deficient) and W335 (extremely deficient) GA slow-growing mutants, those authors showed that the shoot constituted the main target for GA action. Accordingly, as growth in shoot elongation was much smaller in GA-deficient tomato plants much more assimilate was left to be partitioned into the roots as compared with the wild type plants. Summarizing, this dry mass accumulation pattern was due to stem growth as affected by GAs and not to be regulator by itself. Since total dry mass in sunflower plants did not respond to the regulators herein employed being kept more or less constant (Table 2), a good theoretical exercise would be to forecast where the assimilates would come from in case the cells affected by $\mathrm{GA}_{3}$ would accumulated dry mass to their full potential.

In summary when investigating the effects of autoclaving in PBZ physiological action on the growth and dry mass partition in sunflower seedlings, no significant difference in the inhibitory effects of autoclaved and non-autoclaved form was found and in the reversion of those effects by $\mathrm{GA}_{3}$, as well. Hence, the amounts (levels) of autoclaved PBZ employed in aseptic cultures or used for other purposes in laboratory or field conditions could be considered as the real one and equivalent to the amounts of the non-autoclaved form. This has already been put forward in [10], without showing any evidence, however. As expected the main effects of PBZ and $\mathrm{GA}_{3}$ were observed in shortening and elongation of seedlings stems, respectively. The body of evidences leads to the 
conclusion that GA deficiency caused by PBZ (or in GA-deficient mutants) resulted in a pronounced stem growth decrease and hence as stem-root system dry mass did not vary to a large extent, assimilates are directed towards the roots. Unequivocally, in the present investigation, not at all affected by both $\mathrm{GA}_{3}$ and PBZ (autoclaved and non-autoclaved) were mean leaf and internode number, total plant dry mass, leaf dry mass per plant, and the stem-root system dry mass per plant as a whole.

\section{ACKNOWLEDGMENTS}

Thanks are due to FAPEMIG (Foundation for Research Sponsoring of Minas Gerais State) for the scholarships granted to DMR (PostDoctoral training), JB and GBR (Scientific Initiation training), and for the financial support in several occasions. CAPES (Coordination for Improvement of Higher Education Training) awarded a scholarship to CM. CNPq (Brazilian Council for Science and Technological Development) has maintained RBS as an associated Fellow Researcher member since long ago.

\section{REFERENCES}

[1] PGRSA (2007) Plant growth regulation handbook of the Plant Growth Regulation Society of America. $4^{\text {th }}$ Edition. The Plant Growth Regulation Society of America, Athens.

[2] ICI (Imperial Chemical Industries) and PLC (1986) Plant protection division. Clipper, Surrey.

[3] Rademarcher, W. (2000) Growth retardants: Effects on gibberellins biosynthesis and other metabolic pathways. Annual Review of Plant Physiology and Plant Molecular Biology, 51, 501-531.

doi:10.1146/annurev.arplant.51.1.501

[4] Kulkarni, V.J. (1988) Chemical control of tree vigour and promotion of flowering and fruiting in mango (Mangifera indica L.) using paclobutrazol. The Journal of Horticultural Science, 63, 557-566.

[5] Wilkinson, R.I. and Richards, D. (1991) Influence of paclobutrazol on growth and flowering of Rhododrendon 'Sir Robert Peal'. HortScience, 26, 282-284.

[6] Tukey, L.D. (1983) Vegetative control and fruiting on mature apple trees treated with PP333. Acta Horticulture, 137, 103-109.

[7] Gosh, A., Chikara, J., Chandhari, D.R., Prakashi, A.R., Boricha, G. and Zala, A. (2010) Paclobutrazol arrests vegetative growth and unveils unexpressed yield potential of Jathropa curcas. Journal of Plant Growth Regulation, 29, 307-315. doi:10.1007/s00344-010-9137-0

[8] Early, J.D. and Martin, G.C. (1988) Translocation and breakdown of 14C-labeled paclobutrazol in 'Nemaguaro' peach seedlings. HortScience, 23, 196-200.

[9] Müller, C. (2007) Efeito do paclobutrazol na germinação e no metabolismo do etileno em sementes de Stylosantes humilis HBK. M.Sc. Dissertation, Universidade Federal de Viçosa, Viçosa.

[10] Snir, I. (1988) Influence of paclobutrazol on in vitro growth of sweet cherry shoots. HortScience, 23, 304-305.
[11] Panaia, M., Senaratna, T., Bunn, E., Dixon, K.W. and Sivasithamparam, K. (2000) Micropropagation of the critically endangered Western Australian species, Symonanthus bancroftii (F. Muell.), L. Haegi (Solanaceae). Plant Cell Tissue and Organ Culture, 63, 23-29. doi:10.1023/A:1006457624282

[12] Albany, N.R., Vilchez, J.A., Garcia, L. and Jiménez, E. (2005) Comparative study of morphological parameters of Grand Nain banana (Musa AAA) after in vitro multiplication with growth retardants. Plant Cell Tissue and Organ Culture, 83, 357-361. doi:10.1007/s11240-005-6307-z

[13] Haughan, P.A., Burden, R.S., Lenton, J. and Goad, J. (1989) Inhibition of celery cell growth and sterol biosynthesis by the enantiomers of paclobutrazol. Phytochemistry, 3, 781-787. doi:10.1016/0031-9422(89)80115-3

[14] Chen, J.-T. and Chang, W.-C. (2003) Effects of GA3, ancymidol, cycocel and paclobutrazol on direct somatic embryogenesis of Oncidium in vitro. Plant Cell Tissue and Organ Culture, 72, 105-108. doi:10.1023/A:1021235700751

[15] Kucharska, D. and Olikowska, T. (2008) The influence of paclobutrazol in the rooting medium on the quality of chrysanthemum vitroplants. The Journal of Fruit and Ornamental Plant Research, 16, 417-424.

[16] Kyte, L. and Kleyn, J. (1996) Plant from test tubes: An introduction to micropropagation. $3^{\text {rd }}$ Edition. Timber Press, Portland.

[17] Richards, F.J. (1969) The quantitative analysis of growth. In: Steward, F.C., Ed., Plant Physiology - a Treatise, Academic Press, New York, 3-76.

[18] Hunt, R., Causton, D.R., Shipley, B. and Askey, A.P. (2002) A modern tool for classical plant growth analysis. Annals of Botany, 90, 485-488. doi:10.1093/aob/mcf214

[19] LeCain, D.R., Schekel, K.A. and Wample, R.L. (1986) Growth retarding effects of paclobutrazol on weeping fig. HortScience, 21, 1150-1152.

[20] Bultynck, L. and Lambers, H. (2004) Effects of applied gibberellic acid and paclobutrazol on leaf expansion and biomass allocation in two Aegilops species with constrasting leaf elongation rates. Physiologia Plantarum, 122, 143-151. doi:10.1111/j.1399-3054.2004.00383.x

[21] Nagel, O.W. and Lambers, H. (2002) Changes in the acquisition and partitioning of carbon and nitrogen in the gibberellin-deficient mutants A70 and W335 of tomato (Solanum lycopersicum L.). Plant, Cell and Environment, 25, 883-891. doi:10.1046/j.1365-3040.2002.00871.x

[22] Auras, N.E. (1997) Efeitos do paclobutrazol sobre a morfologia e anatomia foliar, crescimento e parte aérea, distribuição de biomassa e trocas gasosas em girassol. D.Sc Dissertation, Universidade Federal de Viçosa, Viçosa.

[23] Hunt, R. (1990) Basic growth analysis. Unwin Hyman, London.

[24] Cox, A.C. and Keever, G.J. (1988) Paclobutrazol inhibits growth of Zinnia and Geranium. HortScience, 23, 1029-1030.

[25] Bidadi, H., Yamaguchi, S., Asahina, M. and Satoh, S. (2010) Effects of shoot-applied gibberellin/gibberellinbiosynthesis inhibitors on root growth and expression of gibberellins biosynthesis genes in Arabidopsis thaliana. Plant Root, 4, 4-11. doi:10.3117/plantroot.4.4 
[26] Gou, J., Strauss, S.H., Tsai, C.J., Fang, K., Chen, Y., Jiang, X. and Busov, V.B. (2010) Gibberellins regulate lateral root formation in Populus through interactions with

\section{List of abbreviations:}

CLT: control; DRM: dry mass; GA, GA : gibberellins, gibberellic acid; LFY, leaf; LNT: length; PBZ: pa- auxin and other hormones. The Plant Cell, 22, 623-635. doi:10.1105/tpc.109.073239

clobutrazol; ROT: root; SHT: shoot; STM: stem; TOT: total. 